\title{
Aspek Biologi Sel T Regulator CD4+ CD25+ pada Transplantasi Sumsum Tulang
}

\author{
Muhaimin Rifa'i * \\ Jurusan Biologi, Fakultas Matematika dan ilmu pengetahuan Alam, Universitas Brawijaya
}

\begin{abstract}
Abstrak
Graft-versus-host disease (GVHD) dan rejeksi (penolakan) pada transplantasi alogenik merupakan kasus terpenting pada masalah transplantasi jaringan. Di lain pihak ketersediaan donor dengan kriteria MHC-matching sangat terbatas. Fakta bahwa kebanyakan organisme hidup sehat tanpa terjangkit penyakit autoimun menunjukkan adanya mekanisme regulasi yang mampu mencegah teraktivasinya sel-sel autoreaktif. Organisme mempunyai mekanisme yang sangat sempurna untuk menghindari respon mematikan terhadap self-antigen. Mekanisme terpenting pada toleransi imunologi ini adalah yang diperankan oleh sel T regulator. Mekanisme toleransi yang dilakukan oleh sel T regulator mencegah teraktivasinya sel-sel autoreaktif ini nampaknya juga terjadi pada transplantasi, baik transplantasi sumsum tulang maupun organ. Pada review ini kami akan membahas aplikasi sel T regulator $\mathrm{CD} 4^{+} \mathrm{CD} 25^{+}$pada transplantasi alogenik terutama pada transplantasi sumsum tulang (bone marrow transplantation, BMT).
\end{abstract}

Kata kunci: sel T regulator, transplantasi sumsum tulang, toleransi imunologi

\begin{abstract}
Graft-versus-host disease (GVHD) and rejection on alogenic transplant is the most important case in tissues transplant. On the other hand, the availability of donor with MHC-matching criteria was limited. The fact that most organisms live healthy without autoimmune disease indicate a regulatory mechanism that prevents activation of autoreactive cells. Organisms have perfect mechanisms for avoiding the deadly response to the self-antigen. The most important mechanisms of immunological tolerance are played by regulatory $T$ cells. Mechanisms of tolerance by regulatory $T$ cells prevents activation of these autoreactive cells were also appears to occur in transplant, either bone marrow or organ transplant. This review discusses the application of regulatory $\mathrm{T}$ cells in $\mathrm{CD} 4{ }^{+} \mathrm{CD} 25{ }^{+}$allogenic transplantation, especially in bone marrow transplant (BMT).
\end{abstract}

Keywords: T-cell regulator, bone marrow tranplant, immunological tolerance

\section{PENDAHULUAN}

Seiring dengan perkembangan ilmu di bidang biologi-kedokteran, saat ini transplantasi sumsum tulang (bone marrow transplant-BMT) telah menjadi salah satu strategi untuk mengatasi penyakit turunan maupun penyakit yang timbul akibat pengaruh lingkungan. Di antara penyakit turunan yang telah diatasi dengan transplantasi sumsum tulang misalnya imunodefisiensi dan hemoglobinofati. BMT juga telah dimanfaatkan untuk mengatasi malignansi misalnya leukaemia, pasien yang menderita anemia berat ataupun penyakit infeksi berat akibat aplasia medullaris. Pada pelaksanaan BMT sangat sulit diperoleh donor yang mempunyai kesamaan MHC secara penuh, sehingga penerima transplantasi (host) akan hidup dengan

\footnotetext{
* Alamat korespondensi:

Muhaimin Rifa'i

Email : rifa123@ub.ac.id

Alamat : Jurusan Biologi, Fakultas MIPA, Universitas Brawijaya, Jl. Veteran, Malang, 65145
}

dua tipe sel yang bersifat aloreaktif pada tubuhnya [1;2;3]. Dalam kondisi seperti ini Graftversus-host disease-GVHD merupakan masalah paling besar yang dapat menyebabkan kematian. Penyebab utama GVHD adalah adanya sel T mature yang ada pada sumsum tulang donor. Penyebab kematian yang lain adalah terjadinya rejeksi (penolakan) donor oleh sistem imun host, sehingga transplantasi gagal sejak awal pelaksanaan. Untuk mengatasi penolakan oleh host umumnya dilakukan kemoterapi dan radiasi total pada host. Kemoterapi yang dilakukan pada kasus ini bertujuan untuk menekan sistem imun host yang umumnya menggunakan cyclosporine atau methotrexate. Pemberian obat-obat imunosupresor meskipun sangat efektif mengontrol rejeksi dan GVHD namun pada akhirnya tidak dapat mengatasi respon imun yang terjadi secara kronik.

Respon imun kronik ini diketahui disebabkan oleh MHC minor $[4 ; 5 ; 6 ; 7]$. Oleh karena itu meskipun diperoleh donor yang mempunyai keselarasan MHC terhadap host 
(MHC-matching) tetap tidak ada jaminan bahwa transplan akan diterima selamanya. Selama proses persiapan dan setelah pelaksanaan BMT akan terjadi efek samping yaitu penurunan kualitas hidup bagi pasien. Defektif perkembangan sel-sel hematopoietik (aplasia) akan terjadi setelah pelaksanaan kemoterapi. Cacat perkembangan sel-sel hematopoietik ini akan menyebabkan terjadinya infeksi yang parah di samping munculnya neoplasma. Neoplasma ini merupakan perkembangan sel yang tidak terkontrol dapat bersifat jinak ataupun malignant. Obat-obat imunosupresan tidak saja menarget sel $\mathrm{T}$ yang dimaksudkan namun juga mengenai sel-sel dan organ lain sehingga mengarah pada kerusakan organ lain [8;9;10;11;12]. Di samping adanya sifat toksisitas yang telah disebutkan ini, obat-obat imunosupresan juga meningkatkan terjadinya resiko leukemia. Mengingat besarnya efek obatobat imunosupresan ini, maka sangat penting dikembangkan strategi yang dapat mengatasi rejeksi dan GVHD namun tidak menghambat kerja sel-sel imunokompeten. Semenjak penemuan Bilingham et al. yang berhasil menginduksi sitem tolerance pada mencit neonatal, maka peneliti-peneliti lain disibukkan untuk mencari tahu mekanisme terjadinya tolerance pada sistem alogenik [2]. Semua karya penelitian tersebut sesungguhnya dimaksudkan mencapai satu tujuan yaitu keberhasilan pada transplantasi alogenik.

Telah diketahui bahwa terjadinya toleransi terhadap sel $\mathrm{T}$ di dalam tubuh individu telah terjadi sejak awal maturasi sel $\mathrm{T}$ pada timus. Teori clonal deletion hanya memberikan kesempatan hidup bagi sel $\mathrm{T}$ yang memenuhi syarat tertentu dan sisanya akan dieliminasi melalui mekanisme apoptosis. Meskipun seleksi pada timus cukup ketat nyatanya masih ada sel T autoreaktif yang lolos dari seleksi negatif sehingga sel-sel tersebut harus dikontrol dengan ketat agar tidak menimbulkan masalah autoimun $[13 ; 14 ; 15 ; 16 ; 17]$. Sistem toleran dan anergy pada periferal diyakini sebagai hasil kerja yang diperankan oleh sel $T$ regulator $\left(T_{\text {reg }}\right)$ yang sekaligus juga berperan sebagai supresor. Pada manusia maupun mencit kegagalan sistem toleran akan berakibat munculnya penyakit autoimun. Penyakit ini selanjutnya diketahui terkait dengan mutasi gen penyandi FOXP3 (forkhead/winged helix transcription factor). Mutasi pada gen ini akan menimbulkan IPEX (Immune dysregulation, polyendocrinopathy, enteropathy, $X$-linked) pada manusia. Mencit scurfy merupakan salah satu contoh hewan percobaan yang mengalami mutasi pada gen FOXP3. Mencit ini akan segera mati akibat penyakit autoimun. FOXP3 selanjutnya diketahui berperan penting pada perkembangan sel $T$ regulator, $\mathrm{CD} 4^{+} \mathrm{CD} 25^{+}$. Mencit IL-2 $\mathrm{R} \beta^{-/-}$juga merupakan model mencit eksperimen yang menderita autoimun. Pada mencit jenis terakhir ini meskipun gen FOXP3 tidak cacat namun mencit ini juga tidak mempunyai sel $\mathrm{T}$ regulator, $\mathrm{CD} 4^{+} \mathrm{CD} 25^{+}$. Mencit scurfy maupun IL-2 $\mathrm{R} \beta^{-/-}$yang menerima infus sel $T$ regulator akan bidup normal dan bebas dari penyakit autoimun. Dengan demikian jelaslah bahwa komponen utama yang mendukung terselenggaranya homeostasis normal adalah sel $\mathrm{T}$ regulator $\mathrm{CD}^{+} \mathrm{CD}^{+} 5^{+}[18 ; 19 ; 20 ; 21]$.

\section{SEL T REGULATOR CD ${ }^{+} \mathrm{CD}^{2} 5^{+}$FOXP3 $^{+}$}

Pada saat ini para ilmuwan meyakini bahwa sitem toleran pada individu sehat diperankan oleh banyak sel $\mathrm{T}$ regulator yang berasal dari populasi sel T. Di antara sel $\mathrm{T}$ regulator tersebut yang paling penting adalah $\mathrm{CD}^{+} \mathrm{CD}^{+} 5^{+} \mathrm{FOXP3}^{+}$. Sel $\mathrm{T}$ regulator $\mathrm{CD}^{+} \mathrm{CD}^{+} 5^{+} \mathrm{FOXP3}^{+}$diketahui berkembang dan terseleksi pada organ timus. Banyak laporan yang berbeda mengenai perkembangan sel T regulator $\mathrm{CD} 4^{+} \mathrm{CD} 25^{+} \mathrm{FOXP3}^{+}$. Satu grup melaporkan bahwa prekursor sel $T$ regulator $\mathrm{CD}^{+} \mathrm{CD}^{2} 5^{+} \mathrm{FOXP3}^{+}$dapat mengalami seleksi negatif oleh APC, namun grup peneliti lain melaporkan bahwa prekursor sel $\mathrm{T}$ regulator $\mathrm{CD}^{+} \mathrm{CD}^{+} 5^{+} \mathrm{FOXP3}^{+}$resisten terhadap mekanisme clonal deletion (negative selection) pada epitel timus $[22 ; 23 ; 24 ; 25 ; 26]$.

Sampai saat ini perkembangan sel $T$ regulator ini masih merupakan misteri, namun para ilmuwan sudah menemukan persamaan pandang bahwa sel ini mempunyai afinitas ikatan yang tinggi dengan MHC kelas I dan hampir menjadi target seleksi negatif. Mengingat seleksi klon $\mathrm{T}_{\text {reg }}$ berada pada afinitas $\mathrm{MHC}$ kelas I yang tinggi, $T_{\text {reg }}$ mempunyai kecenderungan menjadi self-reactive. Sifat ini sangat penting karena salah satu mekanisme kerja $\mathrm{T}_{\text {reg }}$ adalah menarget dan mengontrol sel autoreaktif dengan cara kontak antar sel $[27 ; 28 ; 29 ; 30]$.

$\mathrm{T}_{\text {reg }}$ pada mencit muncul setelah hari ketiga. Timektomi sebelum hari ketiga berakibat munculnya penyakit autoimun pada mencit model tersebut, sebaliknya jika dilakukan setelah hari ketiga mencit tetap hidup normal. Setelah hari ketiga sel $\mathrm{T}_{\text {reg }}$ telah berada pada organ limfoid periferal dan $T_{\text {reg }}$ tersebut akan terus berproliferasi secara homeostasis untuk 
memenuhi kebutuhan fisiologi individu yang bersangkutan. Mencit yang mengalami gangguan autoimun juga akan sembuh jika ditransfer dengan sel T regulator $\mathrm{CD} 4^{+} \mathrm{CD} 25^{+}$atau ditransfer dengan total limfosit dari mencit yang umurnya lebih dari tiga hari. $\mathrm{T}_{\text {reg }}$ berproliferasi dengan memanfaatkan interleukin-2 (IL-2). $\mathrm{T}_{\text {reg }}$ yang teraktivasi akan melakukan kerjanya yaitu menekan reaktivitas sel-sel autoregresif. $T_{\text {reg }}$ akan teraktivasi jika terjadi ikatan CTLA-4 yang ada pada permukaan $\mathrm{T}_{\text {reg }}$ dengan molekul CD80/CD86 yang berada pada permukaan APC. Ikatan CTLA4:CD80/CD86 akan meningkatkan ekspresi IDO (Indoleamine 2, 3-dioxygenase) pada APC. Peningkatan IDO akan menghabiskan ketersediaan triptofan pada daerah di sekitar APC tersebut. Keadaan ini mengakibatkan terhentinya proliferasi sel T efektor maupun selsel autoreaktif yang lain. Beberapa fakta yang lain menunjukkan bahwa kurangnya triptofan akan menyebabkan sel-sel efektor akan melakukan apoptosis [31;32;33].

$\mathrm{T}_{\text {reg }}$ tidak saja mencegah munculnya penyakit autoimun, namun dapat mengontrol sel $\mathrm{T}$ reaktif pada IBD sehingga inflamasi dapat dihindari. Dari perspektif ini jelaslah bahwa $T_{\text {reg }}$ tidak saja berguna sebagai agen preventif namun juga kuratif. Terjadinya supresi oleh $\mathrm{T}_{\text {reg }}$ diperantarai oleh molekul efektor IL-10 dan TGF- $\beta$ yang dihasilkan oleh $\mathrm{T}_{\text {reg. }}$. Prasyarat lain untuk terlaksananya supresi bahwa target harus peka terhadap TGF- $\beta$. Dalam kaidah ini jelaslah bahwa $\mathrm{T}_{\text {reg }}$ tidak akan efektif terhadap sel-sel autoreaktif yang berasal dari mencit TGF- $\beta^{-1-}$. Telah diketahui $\mathrm{T}_{\text {reg }}$ mempunyai peran yang sangat penting pada inplantasi vetus pada rahim induknya. Diketahui pula $\mathrm{T}_{\text {reg }}$ juga menghambat sel-sel efektor yang mestinya bekerja mengatasi virus, parasit, bakteri, dan fungi. Efek samping kerja $T_{\text {reg }}$ ini menjadi masalah penting pada terapi menggunakan $T_{\text {reg}}$, karena $T_{\text {reg }}$ juga menekan selsel anti-tumor baik dari populasi sel T sitotoksik, NK maupun sel-sel imun lain tanpa spesifitas. $T_{\text {reg }}$ yang telah teraktivasi oleh suatu antigen tidak saja melakukan supresi terhadap sel pembawa antigen tersebut namun $\mathrm{T}_{\text {reg }}$ akan melakukan kerja nonspesifik pada seluruh sel-sel efektor, sehingga penggunaan $T_{\text {reg }}$ pada terapi harus memperhitungkan hal-hal yang terkait dengan pentingnya fungsi sel efektor [34;35;36;37;38].

Ekspresi molekul CD25 pada limfosit T tidak serta merta mewujudkan sel $\mathrm{T}$ regulator. Hal ini terkait fakta bahwa sel yang teraktivasi akan memunculkan molekul ini sebagai konsekuensi kepentingan proliferasi dimana pada saat itu sel membutuhkan IL-2 sedangkan CD25 merupakan IL-2R $\alpha$. Sebaliknya sel $T$ yang tidak mengekspresikan molekul CD25 pun dapat berfungsi sebagai sel $\mathrm{T}$ regulator apabila sel tersebut mengekspresikan FOXP3. Dalam tinjauan ini keberadaan FOXP3 lebih penting untuk menjadi klaim sebagai sel $\mathrm{T}$ regulator, namun demikian marker CD25 tetaplah cara termudah untuk memperoleh sel $\mathrm{T}$ regulator. Pada berbagai eksperiman telah diketahui $\mathrm{CD} 4^{+} \mathrm{CD} 25^{-} \mathrm{FOXP3}^{+}$terbukti mempunyai kapasitas yang sama dengan sel $\mathrm{T}$ regulator $\mathrm{CD} 4^{+} \mathrm{CD} 25^{+}$. Dengan adanya fakta ini peneliti telah melakukan kajian mendalam ternyata pada individu yang relatif muda hampir dipastikan bahwa $\mathrm{CD} 4^{+} \mathrm{CD} 25^{+}$ merupakan sel $\mathrm{T}$ regulator yang mengekspresikan FOXP3. Sehingga untuk memperoleh sel $T$ regulator dari mencit diperlukan mencit berumur di bawah 10 minggu dan cukup mengisolasi $\mathrm{CD} 4{ }^{+} \mathrm{CD} 25^{+}$untuk memperoleh sel $\mathrm{T}$ regulator [39;40].

Jauh sebelum mekanisme toleran diketahui, grup peneliti Nicole Le Douarin et al. telah melakukan xeno-transplantasi dimana epitelium timus dipindahkan ke spesies lain pada saat embrio. Ternyata embrio tersebut pada hidupnya toleran terhadap jaringan yang berasal dari donor yang sebelumnya telah menyumbangkan epitelium itu. Hasil ini menjadi bukti berjalannya mekanisme toleransi melalui manipulasi imunologi. Pada saat Nicole Le Douarin et al. memperoleh hasil tersebut belum banyak yang bisa dijelaskan, namun pada saat ini diketahui bahwa mekanisme toleran dimediasi oleh kerja

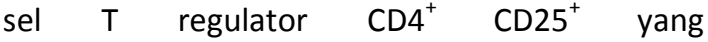
perkembangannya mutlak memerlukan timus $[41 ; 42]$.

\section{GRAFT-VERSUS-HOST DISEASE (GVHD)}

Pada kasus terjadinya kanker darah pasien diberi terapi dengan kemoterapi maupun radiasi. Terapi ini dimaksudkan untuk menghilangkan baik sel-sel limfosit maupun mieloid. Namun demikian ablasi in vivo pada sel limfosit maupun mieloid tidak sepenuhnya bisa menghilangkan sel-sel ini. Sel-sel yang tersisa ini pada akhirnya menjadi salah satu faktor penyebab rejeksi maupun GVHD. Saat ini diketahui bahwa faktor paling penting yang memperburuk transplantasi sumsum tulang adalah adanya kontiminasi sel $\mathrm{T}$ mature donor. Untuk mengatasi masalah ini, dengan mudah para peneliti melakukan deplesi sel T mature donor. Inkubasi sel donor dengan anti-CD3 atau anti-Thy1.2 selama 30 menit diikuti 
dengan penambahan komplemen akan menyebabkan semua sel T mature mati akibat reaksi komplemen in vitro. Namun demikian pada akhir-akhir ini timbul masalah baru, karena terbukti sel-sel T mature yang dianggap sebagai sel kontaminan ini ternyata sangat dibutuhkan untuk memusnahkan sel-sel kanker darah yang tersisa, yang selanjutnya dikenal dengan istilah GVL (graft-versus-leukemia). Dalam pandangan terakhir ini maka untuk mengatakan bahwa BMT berjalan sukses harus dipenuhi kriteria terjadi toleransi dimana tidak terdapat rejeksi maupun GVHD dan mekanisme GVL tetap berjalan dengan sempurna [43].

Untuk memperoleh toleran ini dapat dilakukan dengan cara melakukan transfusi sumsum tulang yang sebelumnya telah diblocking dengan berbagai antibodi yang spesifik untuk sel $\mathrm{T}$ ataupun dengan cara mem-blocking ligannya, misalnya dengan melakukan staining dengan anti-CD4, CD8, anti-B7, dan anti-CD154 yang dikuti dengan komplemen. Pada percobaan yang dilakukan oleh Johnson dimana mencit diradiasi dengan dosis letal dan diinjeksi dengan sumsum tulang yang sebelumnya telah dilakukan deplesi sel T, mencit tidak mengalami GVHD. Ketika lima minggu setelah BMT dilakukan infuse sel T donor, mencit tetap tidak mengalami GVHD. Sebaliknya jika sebelum menginfusi sel $\mathrm{T}$ donor itu mencit diinjeksi in vivo dengan antibodi yang mendeplesi sel T maka mencit menderita GVHD yang mematikan. Percobaan ini memberikan informasi bahwa sel $\mathrm{T}$ donor telah berkembang menjadi sel $\mathrm{T}$ regulator pada timus host, sehingga ketika sel $\mathrm{T}$ donor pada minggu ke lima ditambahkan tidak akan menimbulkan GVHD karena sel $\mathrm{T}$ tersebut dapat diregulasi oleh sel $\mathrm{T}_{\text {reg }}$ yang telah ada. Sebaliknya jika sebelum menerima sel $\mathrm{T}$ donor sel $\mathrm{T}$ dideplesi terlebih dahulu, maka semua sel $\mathrm{T}$ termasuk sel $\mathrm{T}_{\text {reg }}$ telah hilang pada mencit tersebut sehingga sel $\mathrm{T}$ yang diinjeksikan berikutnya tidak dapat diregulasi dan akan berkembang menjadi efektor yang menyebabkan GVHD. Bentuk percobaan yang pendekatannya menyerupai kejadian GVHD akut pada klinik awalnya dilakukan pada laboratorium Strober, Blazar, dan Salomon. Pada mencit yang diradiasi dengan dosis letal dan diinfusi dengan sel T donor, host akan menderita GVHD setelah beberapa minggu. Pada model ini deplesi sel T yang membawa molekul CD25 akan memacu GVHD dan letal lebih cepat $[44 ; 45 ; 46]$. Sebaliknya penambahan sel $\mathrm{T}$ donor $\mathrm{CD} 4^{+} \mathrm{CD} 25^{+}$akan menunda GVHD, terutama jika sel $\mathrm{T}_{\text {reg }}$ yang ditambahkan cukup besar misalnya 1:1 untuk perbandingan sel $\mathrm{T}$ yang diinfusikan atas sel $\mathrm{T}_{\text {reg }}$ yang ditambahkan $[44 ; 45 ; 46 ; 47]$.

Dalam percobaan yang dilakukan oleh para ilmuwan sejauh ini hasil percobaan menggunakan $T_{\text {reg }}$ mempunyai hasil yang bervariasi mulai dari tertundanya GVHD sampai terjadi proteksi penuh sehingga mencit hasil transplantasi hidup sehat setidaknya sampai 3 bulan pasca transplantasi. Sejauh ini belum ada yang bisa menjelaskan namun diduga sangat dipengaruhi oleh jumlah sel $\mathrm{T}$ regulator dan jumlah sel efektor. Hasil yang sama juga terjadi pada percobaan GVHD yang diinduksi dengan infusi splenosit yang berbeda pada MHC-minor. Pada sistem ini $\mathrm{T}_{\text {reg }}$ donor dan host sama-sama berperan mencegah terjadinya GVHD [48]. Untuk mengatasi GVHD nampaknya memerlukan sel $\mathrm{T}_{\text {reg }}$ dalam jumlah yang banyak, yaitu untuk mengimbangi sel $\mathrm{T}$ efektor. Namun sayangnya $\mathrm{T}_{\text {reg }}$ khususnya $\mathrm{CD} 4^{+} \mathrm{CD} 25^{+}$bersifat non-responsif terhadap stimuli melalui jalur TCR ( $T$-cell reseptor). Strategi pengembangan $\mathrm{T}_{\text {reg }}$ in vitro ini sangat penting untuk memenuhi kebutuhan $\mathrm{T}_{\text {reg }}$ pada pelaksanaan terapi. Oleh karena itu harus diketahui apakah $\mathrm{T}_{\text {reg }}$ hasil ekspansi in vitro juga efektif untuk melakukan supresi in vivo $[44 ; 45 ; 46 ; 47 ; 48]$.

Meskipun pada stimuli dengan anti-CD3 $\mathrm{T}_{\text {reg }}$ bersifat anergi (nonresponsive) namun strategi dengan menggunakan stimuli anti-CD3/CD28 ditambah IL-2 ternyata mampu menstimuli proliferasi hingga $10^{4}$ kali lipat pada kultur minggu ke-6 [49]. Mencit diinfusi dengan sel sumsum tulang yang dicampur dengan sel $\mathrm{T}$ dan dimasukkan ke host bersama $\mathrm{T}_{\text {reg }}$ yang dikembangkan in vitro. Pada desain penelitian ini kejadian GVHD dapat dihindarkan [50]. Penambahan TGF-beta secara in vitro pada kultur $\mathrm{T}_{\text {reg }}$ dapat meningkatkandaya proteksi $\mathrm{T}_{\text {reg. }}$. Hasil ini menggambarkan meskipun secara klinik jumlah $\mathrm{T}_{\text {reg }}$ yang dapat diperoleh dari biopsis pasien, propagasi in vitro dapat dilakukan dengan mudah sehingga sel $\mathrm{T}$ regulator untuk terapi GVHD semakin menjanjikan dan mudah dikerjakan. Ke depan diyakini bahwa pemenuhan kebutuhant $_{\text {reg }}$ untuk terapi akan menggunakan sistem in vitro. $\mathrm{T}_{\text {reg }}$ pihak donor yang dikembangkan in vitro bersama sel host mempunyai efektivitas yang lebih baik untuk mencegah terjadinya GVHD. $\mathrm{T}_{\text {reg }}$ yang dikembangkan dengan cara menstimulasi dengan anti-CD3 tidak efisien untuk mengatasi GVHD, sebaliknya yang dikembangkan dengan cara menstimulasi dengan APC tipe host akan sangat efisien menghambat terjadinya GVHD [51]. 
Telah diketahui bahwa $\mathrm{T}_{\text {reg }}$ yang spesifik pada antigen host akan lebih survival jika diinfusikan pada host. Untuk tujuan terapi, sel $\mathrm{T}_{\text {reg }}$ akan distimuli dengan APC tipe host agar diperoleh fungsi optimum dalam melakukan regulasi. Sel $\mathrm{T}_{\text {reg }}$ dari host juga mempunyai kontribusi mencegah terjadinya GVHD. Telah diketahui bahwa sel $T$ regulator bekerja secara nonspesifik. Artinya ketika $\mathrm{T}_{\text {reg }}$ telah menjadi efektor, sitokin yang dihasilkan dapat bekerja pada semua sel yang teraktivasi tidak terkait dengan antigen yang menyebabkan aktivasi itu. Trenado et al., melaporkan bahwa $\mathrm{T}_{\text {reg }}$ yang distimuli dengan APC host jauh lebih efisien daripada jika APC berasal dari spesies lain yang tidak dikenal. Hal ini diduga $\mathrm{T}_{\text {reg }}$ yang teraktivasi in vitro tersebut langsung bekerja dan bisa mengenali targetnya ketika berada pada sirkulasi host. Pada studi menggunakan $T_{\text {reg }}$ dari mencit transgenik, GVHD dapat dihambat jika $T_{\text {reg }}$ mendapat stimuli antigen yang sesuai $(2-4,44)$.

Dalam hal ini ketika mencit transgenik tersebut spesifik untuk OVA, maka GVHD hanya dapat dihambat jika host diberi stimuli OVA untuk mengaktifkan $\mathrm{T}_{\text {reg }}$ yang diinjeksikan. Hasil penelitian yang telah dilaporkan oleh banyak ilmuwan hampir dapat disimpulkan bahwa $\mathrm{T}_{\text {reg }}$ memerlukan antigen spesifik untuk terjadinya aktivasi dan berubah menjadi efektor, namun kerja selanjutnya tidak terkait dengan antigen yang menstimuli itu. Dalam penelitian lain diterangkan bahwa sel $\mathrm{T} \mathrm{CD}^{+}$yang ditransduksi dengan FOXP3 dapat menghambat GVHD dengan sangat efisien jika $T_{\text {reg }}$ yang dimaksud mengenal salah satu antigen host. Pada keterangan terakhir ini menjadi gambaran bahwa $T_{\text {reg }}$ bekerja tidak selalu menggunakan antigen spesifik secara absulut, namun yang dibutuhkan adalah adanya antigen yang bisa dikenali sehingga tercapai fase efektor. $T_{\text {reg }}$ yang bekerja secara aktif ternyata mengekspresikan molekul CD62L pada level yang tinggi. CD62L merupakan molekul adhesi untuk homing, dengan demikian diperkirakan bahwa $T_{\text {reg }}$ bekerja dengan efisien pada limfoid sekunder untuk melakukan fungsi sebagai sel $\mathrm{T}$ regulator [49; 51].

$\mathrm{T}_{\text {reg }}$ bekerja dengan menekan proliferasi dan fungsi efektor targetnya. Untuk mengatasi GVHD $\mathrm{T}_{\text {reg }}$ juga bekerja pada berbagai macam jaringan seperti kulit, paru, liver, dan saluran pencernakan. Molekul CCR5 diperlukan oleh $\mathrm{T}_{\text {reg }}$ untuk homing pada jaringan-jaringan target [52]. Pada eksperimen model colitis sitokin yang diketahui berperan sebagai imunosupresor adalah IL-10 dan TGF-beta. Pada eksperimen model GVHD sampai saat ini hanya IL-10 yang dilaporkan terlibat sebagai molekul supresor $[4 ; 5 ; 6]$.

Pada percobaan menggunakan $T_{\text {reg }}$ yang langsung diisolasi dari mencit normal tipe donor ternyata mampu mencegah GVHD dan bebas dari kematian karena GVHD. Sebaliknya injeksi $T_{\text {reg }}$ yang diisolasi dari IL-10 ${ }^{-/-}$hanya menunda efek letal GVHD dan hanya $40 \%$ yang hidup setelah 3 bulan transplantasi. Mencit yang tersisa inipun menunjukkan GVHD dengan sangat jelas. Dengan demikian dapat dikatakan bahwa IL-10 mempunyai peranan yang sangat penting sebagai molekul supresor bagi $T_{\text {reg }}$ namun bukan satusatunya faktor yang digunakan untuk mencegah terjadinya GVHD. CTLA-4 dan TGF-beta berperan pada sebagian mekanisme perlindungan terhadap GVHD pada tercobaan menggunakan $\mathrm{T}_{\text {reg }}$ yang diisolasi dari mencit $\mathrm{IL}-10^{-/-}$. $\mathrm{T}_{\text {reg }}$ dapat menggunakan berbagai macam mekanisme efektor untuk dapat bekerja. Studi GVHD menggunakan mencit umumnya dilakukan selama tiga bulan dari awal transplantasi, hal ini sangat berhubungan dengan masa hidup mencit. Namun manusia mempunyai masa hidup yang lebih panjang daripada mencit, sehingga efek kronis harus terus diikuti. Pada percobaan BMT alogenik yang pernah dilakukan oleh Taylor et al., yaitu analisis 7 bulan setelah transplantasi ditemukan beberapa informasi antara lain terjadi GVHD yang serius pada ognan paru, kulit, usus, liver, dan limpa [43].

Dengan demikian meskipun nampaknya $T_{\text {reg }}$ dapat melindungi host dari GVHD dan tanda klinik lainnya seperti berkurangnya bobot badan, tidak ada gangguan, namun ternyata tidak sepenuhnya dapat melindungi GVHD selama hidup. Hal ini dimungkinkan karena adanya MHCminor yang selanjutnya menstimuli sel T sehingga berkembang menjadi sel-sel efektor yang dapat melakukan infiltrasi pada berbagai organ secara kronis. $T_{\text {reg }}$ yang diinjeksikan tidak akan hidup dalam waktu yang sangat panjang, sehingga aplikasi $T_{\text {reg }}$ perlu diulang sesuai dengan kebutuhan. Namun demikian ada dugaan bahwa $\mathrm{T}_{\text {reg }}$ yang diinjeksikan akan terus berkembang sesuai dengan homeostasis dan sel tersebut secara "cerdas" akan berproliferasi sesuai dengan kebutuhan fisiologi. Gejala GVHD yang muncul dalam waktu yang relatif lama setelah pelaksanaan transplantasi kemungkinan juga sebagai akibat reaksi de novo yaitu aktivitas dari sel-sel autoreaktif yang lolos dari proses seleksi negatif. Pada transplantasi alogenik dalam waktu yang panjang memungkinkan terjadinya 
gangguan seleksi negatif sehingga sel-sel autoreaktif tetap hidup. Gangguan mekanisme seleksi negatif (clonal deletion) ini disebabkan oleh MHC yang tidak selaras (MHC mismatching) antara epitelium timus host dengan APC yang berkembang dari donor. Pada pelaksanaan BMT, kemoterapi maupun radiasi tidak dapat menghilangkan sel-sel resisten baik dari populasi sel T maupun APC host. Sisa-sisa sel tersebut pada akhirnya akan teraktivasi dan menjadi penyebab timbulnya GVHD [51;52].

Menurut pemahaman sejauh ini, bahwa sel sumsum tulang yang ditransplantasi akan berkembang menjadi sel-sel hematopoietik dan khususnya sel $\mathrm{T}$ akan mengalami seleksi pada timus host. Dengan demikian hanya sel-sel toleran yang akan lulus hidup. Jika sel sumsum tulang yang ditransplantasikan terkontaminasi sel T mature akan terjadi aloreaktif. Oleh karena itu inhibisi GVHD oleh $\mathrm{T}_{\text {reg }}$ hakekatnya sama dengan melakukan deplesi sel mature sebelum transplantasi, keduanya dimaksudkan untuk memperoleh toleran sehingga tidak terjadi serangan sistem imun pada host atau sebaliknya. Edinger et al., Rifa'i et al., dan Trenado et al., menunjukkan bahwa $\mathrm{T}_{\text {reg }}$ secara signifikan menghambat terjadinya GVHD pada sistem alogenik khususnya $B A L B / C$ yang ditransfusi dengan C57BL/6 [8;10;12;44;53]. Ketika mencit ini selanjutnya diinjeksi dengan sel kanker A20, sel kanker akan dibunuh oleh sel dari C57BL/6 dan GVHD tetap saja terhambat. Dalam kaidah ini nampaknya sel $\mathrm{T}_{\text {reg }}$ merupakan sel cerdas yang dapat membedakan antara GVHD dan GVL, dalam kaitan ini $\mathrm{T}_{\text {reg }}$ hanya menghambat GVHD sehingga keberadaannya tidak merugikan dan GVL tetap terjadinya. Sampai saat ini tidak diketahui bagaimana $T_{\text {reg }}$ membedakan GVHD dan GVL. Meskipun disebut-sebut sebelumnya bahwa $T_{\text {reg }}$ bekerja nonspesifik namun ada kecenderungan bahwa $T_{\text {reg }}$ lebih efisien menghambat aktivasi CD4 daripada CD8. Berbeda dari penelitian sebelumnya Cohen et al. menyatakan bahwa $\mathrm{T}_{\text {reg }}$ tidak dapat membedakan antara GVHD dari GVL. Akhir-akhir ini ada pertimbangan untuk tidak menghilangkan sel $T$ yang mengkontaminasi sumsum tulang sebelum pelaksanaan BMT. Sel $\mathrm{T}$ yang terikut pada sumsum tulang tersebut diduga meningkatkan engraftment sel mieloid dan limfosit [44].

\section{PENOLAKAN TRANSPLAN OLEH HOST}

Transplantasi sumsum tulang tidak saja terhambat oleh masalah GVHD tetapi juga masalah rejeksi oleh host. Tata pelaksanaan BMT dengan obat-obat imunosupresif dapat menimbulkan efek samping yang sangat berat. Radiasi dan kemoterapi dapat menyebabkan kerusakan jaringan yang sangat parah terutama pada jaringan yang tersusun oleh sel-sel yang normalnya berproliferasi sangat cepat misal paru-paru dan intestinum. Pasca transplantasi memicu terjadinya infeksi dan keracunan hepar, hal ini banyak disebabkan karena sebelum pelaksanaan transplantasi menggunakan obatobat imunosupresan. Dalam percobaan yang dilakukan oleh Rifa'i et al., sel sumsum tulang mencit $\mathrm{BABL} / \mathrm{c}$ yang ditransfusikan ke mencit IL$2 \mathrm{R} \beta^{\%}$ dengan background $\mathrm{C} 57 \mathrm{BL} / 6$ ternyata terjadi kimera pada sel-sel hematopoietik (data tidak dipublikasi). Dalam hal ini terjadi toleransi pada sistem alogenik ini dan dua sel alogenik berkembang tanpa menunjukkan aloreaktif. Toleransi ini dapat terjadi jika transplantasi dilakukan sedini mungkin misal mencit belum berumur lebih dari tiga hari. Untuk mencit yang telah dewasa penolakan akan terjadi sangat cepat dan tidak ada sel donor yang dapat dideteksi setelah 7 hari transfusi. Untuk mencit dewasa, dengan radiasi dosis letal memungkinkan sel-sel sumsum tulang donor alogenik diterima oleh host dan terjadi toleransi. Demikian juga apabila infusi sumsum tulang (bone marrow, BM) berasal dari campuran (50\%:50\%) tipe donor dan host, radiasi letal dosis memediasi terjadinya toleransi dan sel berkembang saling berdampingan dan terjadi toleransi. Pada kasus yang terakhir ini diduga selsel $\mathrm{T}$ donor maupun host telah melalui seleksi pada timus host sehingga hanya sel-sel toleran yang dapat hidup sedang yang lain akan dieliminasi dengan mekanisme apoptosis. Pada percobaan yang dilakukan oleh Waldmann et al., tingkat keberhasilan BMT alogenik semakin tinggi apabila host diinjeksi dengan antibodi yang dapat mengeliminasi sel T [45].

Pendekatan yang terbaik untuk memperoleh toleransi imunologi pada sistem alogenik adalah dengan menginjeksikan professional regulatory $T$ cells, baik pada transplantasi sumsum tulang maupun transplantasi organ. Dalam kajian keseluruhan dan informasi yang ada pada awalnya diduga bahwa sel $\mathrm{T}$ regulator yang baru diisolasi dari donor akan lebih efektif dibandingakan dengan $\mathrm{T}_{\text {reg }}$ yang dikembangkan in vitro. Pada percobaan sistem alogenik dimana host diradiasi dengan dosis letal dan ditransfusi dengan BM singenik dan BM alogenik kemudian ditambahkan sel T dari host, ternyata terjadi penolakan sel donor 
dengan sangat cepat. Dalam hal ini mudah dipahami bahwa sel mature tipe host akan mengeliminasi donor. Pada percobaan yang sama ketika $\mathrm{T}_{\text {reg }} \mathrm{CD}^{+} \mathrm{CD} 25^{+}$ditambahkan ternyata tidak mampu membantu penerimaan donor oleh host. Pada kasus ini rejeksi yang dilakukan oleh sel-sel mature tersebut tidak mampu dihentikan oleh sel regulator yang ditambahkan. Hal yang sangat menarik ketika dilakukan injeksi dengan $\mathrm{T}_{\text {reg }}$ yang sebelumnya distimuli dengan APC tipe donor secara in vitro ternyata dapat mempertahankan donor dari eliminasi sistem imun host. Hasil yang diutarakan terakhir ini menjadi hal yang sangat menarik karena $T_{\text {reg }}$ yang dikembangkan in vitro sangat efisien dan stimuli in vitro dengan APC tipe donor dan penambahan IL-2 menjadi kunci penting yang harus diteliti lebih lanjut [45].

\section{KESIMPULAN}

$\mathrm{CD}^{+} \mathrm{CD} 25^{+} \mathrm{FOXP}^{+}$merupakan marker yang paling tepat untuk menunjuk sel T regulator. Sel T regulator baik yang berasal dari isolasi langsung ataupun yang dikembangkan in vitro mempunyai daya regulasi yang sangat baik. Sel $\mathrm{T}$ regulator dapat membantu enggrafment donor pada host dan mengatasi atau setidaknya menunda GVHD. Sel T regulator tidak saja menekan aktivitas selsel aloreaktif namun juga menekan semua sel-sel efektor yang normalnya berguna untuk mengatasi infeksi. Jumlah sel $\mathrm{T}$ regulator yang diaplikasi untuk terapi merupakan faktor penting agar GVHD maupun rejeksi dapat teratasi namun sistem imun tetap berjalan dengan baik.

\section{UCAPAN TERIMA KASIH}

Penulisan karya ilmiah ini berhasil diselesaikan atas dukungan dari semua temanteman di laboratorium Fisiologi dan Struktur Perkembangan Hewan UB. Kami sampaikan terima kasih kepada sejawat yang terlibat diskusi pada penulisan artikel ini.

\section{DAFTAR PUSTAKA}

1. Lechler RI, Sykes, AWM. 2005. Thomson and L.A. Turka, Organ transplantation-how much of the promise has been realized? Nat. Med., 11: 605-613.

2. Billingham RE, Brent L, Medawar PB. 1953. Actively acquired tolerance of foreign cells. Nature, 172: 603-606.

3. Waldmann H. 1999. Transplantation tolerance-where do we stand. Nat. Med., 5: 1245-1248.
4. Dai Z, Li Q, Wang. 2004. CD4 ${ }^{+} \mathrm{CD} 25^{+}$regulatory $T$ cells suppress allograft rejection mediated by memory $\mathrm{CD}^{+} \mathrm{T}$ cells via a CD30dependent mechanism. J. Clin. Invest., 113: 310-317.

5. Chen W, Jin W, Hardegen N. 2003. Conversion of peripheral $\mathrm{CD}^{+} \mathrm{CD} 25^{-}$naive $\mathrm{T}$ cells to $\mathrm{CD} 4^{+} \mathrm{CD} 25^{+}$regulatory $\mathrm{T}$ cells by TGF-beta induction of transcription factor Foxp3. J. Exp. Med., 198: 1875-1886.

6. Thornton AM, Donovan EE, Piccirillo CA, Shevach EM. 2004. Cutting edge: IL-2 is critically required for the in vitro activation of $\mathrm{CD} 4{ }^{+} \mathrm{CD} 25^{+} \mathrm{T}$ cell suppressor function. J. Immunol., 172: 6519-6523.

7. Goronzy JJ, Weyand CM. 2011. The innate and adaptive immune systems. In: Goldman L, Schafer Al (Eds.). Cecil Medicine, 24th Ed. Pa: Saunders Elsevier. Philadelphia.

8. Rifa'i M, Kawamoto Y, Nakashima I, Suzuki H. 2004. Essential Roles of $\mathrm{CD}^{+} \mathrm{CD} 122^{+}$ Regulatory T cells in the Maintenance of T Cell Homeostasis. J. of Exp. Med., 200(9): 11231124.

9. Shevach EM. 2000. Regulatory T cells in autoimmunity. Annu. Rev. Immunol., 18: 423449.

10. Ermann J, Hoffmann P, Edinger M. 2005. Only the CD62L+ subpopulation of $\mathrm{CD}^{+} \mathrm{CD} 25^{+}$ regulatory $\mathrm{T}$ cells protects from lethal acute GVHD. Blood, 105: 2220-2226.

11. Chatenoud L, Salomon B, and Bluestone JA. 2001. Suppressor T cells they're back and critical for regulation of autoimmunity. Immunol. Rev., 182: 149-163.

12. Hoffmann $P$, Ermann J, Edinger $M$, Fathman CG, Strober S. 2002. Donor-type $\mathrm{CD} 4^{+} \mathrm{CD} 25^{+}$ regulatory $T$ cells suppress lethal acute graftversus-host disease after allogeneic bone marrow transplantation. J. Exp. Med., 196: 389-399.

13. Samy ET, Parker LA, Sharp CP, Tung KS. 2005. Continuous control of autoimmune disease by antigen-dependent polyclonal $\mathrm{CD}^{+} \mathrm{CD} 25^{+}$ regulatory $T$ cells in the regional lymph node, J. Exp. Med., 202: 771-781.

14. Sakaguchi S. 2004. Naturally arising $\mathrm{CD}^{+}$ regulatory $T$ cells for immunologic selftolerance and negative control of immune responses. Annu. Rev. Immunol., 22: 531-562.

15. Albert MH, Liu Y, Anasetti C, Yu XZ. 2005. Antigen-dependent suppression of alloresponses by Foxp3-induced regulatory $\mathrm{T}$ cells in transplantation. Eur. J. Immunol., 2598-2607. 
16. Suzuki $H$, Kundig TM, Furlonger $C$, Wakeham A, Timms E, Matsuyama T, Schmits R, Simard JJL, Ohashi PS, Griesser H, Taniguchi T, Paige CJ, Mak TW. Deregulated T cell activation and autoimmunity in mice lacking interleukin-2 receptor. Science, 268: 1472-1476.

17. Vieira PL. 2004. IL-10 secreting regulatory $T$ cells do not express Foxp3 but have comparable regulatory function to naturally occuring $\mathrm{CD}^{+} \mathrm{CD} 25^{+}$regulatory $\mathrm{T}$ cells. J. Immunol., 172: 5986-5993.

18. Silva RA, Pais TF, Appelberg R. 2001. Blocking the receptor for IL-10 improves antimycobacterial chemotherapy and vaccination. J. Immunol., 167: 1535-1541.

19. Kane MM, Mosser DM. 2001. The role of IL-10 in promoting disease progression in leishmaniasis. J. Immunol., 166: 1141-1147.

20. Chen W. 2003. Conversion of peripheral $\mathrm{CD}^{+} \mathrm{CD} 25^{-}$naive $\mathrm{T}$ cells to $\mathrm{CD}^{+} \mathrm{CD} 25^{+}$ regulatory $T$ cells by TGF-beta induction of transcription factor Foxp3. J. Exp. Med., 198: 1875-1886.

21. Adeegbe D, Matsutani T, Yang J, Altman $\mathrm{NH}$, Malek TR. 2011. CD4 ${ }^{+} \mathrm{CD} 25^{+}$Foxp3 $^{+} \mathrm{T}$ regulatory cells with limited $T$ cell receptor diversity in control of autoimmunity. J. Immunol., 184(1): 56-66.

22. Weisdorf DJ, Anderson PM, Blazar BR. 1993. Interleukin-2 immediately after autologous bone marrow transplantation for acute lymphoblastic leukemia: a phase I study. Transplantation.

23. Rieger $K$, Loddenkemper $C$, Maul J, Fietz $T$, Wolff D, Terpe H, Steiner B, Berg E, Miehlke S, Bornhauser M, Schneider T, Zeitz M, Stein H, Thiel E, Duchmann R, Uharek L. 2006. Mucosal Foxp3+ regulatory T-cells are numerically deficient in acute and chronic GvHD. Blood, 107(4): 1717-1723.

24. Refaeli Y, Van Parijs L, London CA, Tschopp J, and Abbas AK. 1998. Biochemical mechanisms of IL-2-regulated Fas-mediated $\mathrm{T}$ cell apoptosis. Immunity, 8:615-623.

25. Chai JG, Xue SA, Coe D, Addey C, Bartok I, Scott D, Simpson E, Stauss HJ, Hori S, Sakaguchi S, Dyson J. 2005. Regulatory T cells, derived from naive $\mathrm{CD} 4^{+} \mathrm{CD} 25^{-} \mathrm{T}$ cells by in vitro Foxp3 gene transfer, can induce transplantation tolerance. Transplantation. 79:1310-1316.

26. Wolff D, Gerbitz A, Ayuk F, Kiani A, Hildebrandt GC, Vogelsang GB. 2010. Consensus conference on clinical practice in chronic graft-versus-host disease (GVHD): first-line and topical treatment of chronic GVHD. Biol. Blood Marrow Transplant, 16: 1611-1628.

27. Chu YW, Gress RE. 2008. Murine models of chronic graft-versus-host disease: insights and unresolved issues. Biol. Blood Marrow Transplant, 14: 365-378.

28. Le NT, Chao N. 2007. Regulating regulatory $T$ cells. Bone Marrow Transplant, 39: 1-9.

29. Koreth J, Matsuoka K, Kim HT, McDonough SM, Bindra B, Alyea EP (2006) Interleukin-2 and regulatory $T$ cells in graft-versus-host disease. N. Engl. J. Med., 365: 2055-2066.

30. Malek TR, Castro I. 2010. Interleukin-2 receptor signaling: at the interface between tolerance and immunity. Immunity, 33:153165.

31. Stauber DJ, Debler EW, Horton PA, Smith KA, Wilson IA. 2006. Crystal structure of the IL-2 signaling complex: paradigm for a heterotrimeric cytokine receptor. Proc. Natl. Acad. Sci. USA, 103:2788-2793.

32. Rochman Y, Spolski R, Leonard WJ. 2009. New insights into the regulation of $\mathrm{T}$ cells by gamma(c) family cytokines. Nat. Rev. Immunol., 9: 480-490.

33. Vámosi G, Bodnár A, Vereb G. 2004. IL-2 and IL-15 receptor alpha-subunits are coexpressed in a supramolecular receptor cluster in lipid rafts of T cells. Proc. Natl. Acad. Sci. USA, 101: 11082-11087.

34. Suciu-Foca N, Manavalan JS, Cortesini R. 2003. Generation and function of antigenspecific suppressor and regulatory $\mathrm{T}$ cells. Transpl. Immunol., 11: 235-244.

35. Chai JG, Xue SA, Coe D, Addey C, Bartok I, Scott D, Simpson E, Stauss HJ, Hori S, Sakaguchi S, Dyson J. 2005. Regulatory T cells, derived from naive $\mathrm{CD} 4^{+} \mathrm{CD} 25^{-} \mathrm{T}$ cells by in vitro Foxp3 gene transfer, can induce transplantation tolerance. Transplantation, 79: 1310-1316.

36. Koulnis M, Pop R, Porpiglia E, Shearstone JR, Hidalgo D, Socolovsky M. 2011. Identification and Analysis of Mouse Erythroid Progenitors using the CD71/TER119 Flow-cytometric Assay. J. Vis. Exp., 2011 (54), e2809, doi: 10.3791/2809.

37. Takahashi T, Kuniyasu Y, Toda M, Sakaguchi $\mathrm{N}$, Itoh M, Iwata M, Shimizu J, Sakaguchi S. 1998. Immunologic self-tolerance maintained by $\mathrm{CD} 25^{+} \mathrm{CD} 4^{+}$naturally anergic and suppressive $T$ cells: induction of autoimmune disease by breaking their anergic/suppressive state. Int. Immunol., 10: 1969-1980. 
38. Thornton AM, Shevach EM. 1998. CD4 ${ }^{+} \mathrm{CD} 25^{+}$ immunoregulatory $T$ cells suppress polyclonal $\mathrm{T}$ cell activation in vitro by inhibiting interleukin 2 production. J. Exp. Med., 188: 287-296.

39. Thornton AM, Shevach EM. 2000. Suppressor effector function of $\mathrm{CD} 4^{+} \mathrm{CD} 25^{+}$ immunoregulatory $T$ cells is antigen nonspecific. J. Immunol., 164: 183-190.

40. Setoguchi R, Hori S, Takahashi T, and Sakaguchi S. 2005. Homeostatic maintenance of natural Foxp $3^{+} \mathrm{CD} 25^{+} \mathrm{CD} 4^{+}$regulatory T cells by interleukin (IL)-2 and induction of autoimmune disease by IL-2 neutralization, $J$. Exp. Med., 201: 723-735.

41. Coutinho A, Salaun J, Corbel C, Bandeira A, Le Douarin N. 1993. The role of thymic epithelium in the establishment of transplantation tolerance. Immunol. Rev., 133: 225-240.

42. Modigliani $\mathrm{Y}$, Thomas-Vaslin V, Bandeira $\mathrm{A}$, Coltey $M$, Le Douarin NM, Coutinho A et al. 1995. Lymphocytes selected in allogeneic thymic epithelium mediate dominant tolerance toward tissue grafts of the thymic epithelium haplotype. Proc. Natl. Acad. Sci. USA, 92: 7555-7559.

43. Taylor PA, Panoskaltsis-Mortari A, Swedin JM, Lucas PJ, Gress RE, Levine BL. 2004. LSelectin(hi) but not the L-selectin(lo) $\mathrm{CD} 4^{+} \mathrm{CD} 25^{+}$T-regulatory cells are potent inhibitors of GVHD and BM graft rejection. Blood, 104: 3804-3812.

44. Cohen JL, Trenado A, Vasey D, Klatzmann D, Salomon BL. 2002. CD4 ${ }^{+}$CD25 immunoregulatory $T$ Cells: new therapeutics for graft-versus-host disease. J. Exp. Med., 196: 401-406.

45. H. Waldmann and S. Cobbold. 2001. Regulating the immune response to transplants: a role for $\mathrm{CD}^{+}$regulatory cells?. Immunity 14: pp. 399-406

46. P. Romagnoli, D. Hudrisier and J.P.M. van Meerwijk. 2005. Molecular signature of recent thymic selection events on effector and regulatory $\mathrm{CD}^{+} \mathrm{T}$ lymphocytes. J Immunol 175: pp. 5751-5758.

47. Johnson BD, Konkol MC, Truitt RL. 2002. $\mathrm{CD}_{25}{ }^{+}$immunoregulatory T-cells of donor origin suppress alloreactivity after BMT. Biol. Blood Marrow Transplant, 8: 525-535.

48. Gondek DC, Lu LF, Quezada SA, Sakaguchi S, Noelle RJ. 2005. Cutting edge: contactmediated suppression by $\mathrm{CD}^{+} \mathrm{CD}^{+} 5^{+}$ regulatory cells involves a granzyme $B$ - dependent, perforin-independent mechanism. J. Immunol., 174: 1783-1786.

49. Asano M, Toda M, Sakaguchi N, Sakaguchi S. 1996. Autoimmune disease as a consequence of developmental abnormality of a $\mathrm{T}$ cell subpopulation. J. Exp. Med., 184: 387-396.

50. Setoguchi R, Hori S, Takahashi T, Sakaguchi S. 2005. Homeostatic maintenance of natural Foxp $3^{+} \mathrm{CD} 25^{+} \mathrm{CD} 4^{+}$regulatory $\mathrm{T}$ cells by interleukin (IL)-2 and induction of autoimmune disease by IL-2 neutralization. $J$. Exp. Med., 201: 723-735.

51. Samy ET, Parker LA, Sharp CP, Tung KS. 2005. Continuous control of autoimmune disease by antigen-dependent polyclonal $\mathrm{CD} 4{ }^{+} \mathrm{CD} 25^{+}$ regulatory $T$ cells in the regional lymph node. J. Exp. Med., 202: 771-781.

52. Lechler RI, Garden OA, Turka LA. 2003. The complementary roles of deletion and regulation in transplantation tolerance. Nat. Rev. Immunol., 3: 147-158.

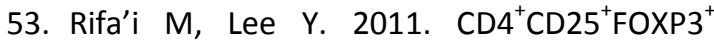
regulatory $T$ cells in allogeneic hematopoietic cell transplantation. JTLS. 1 (2): 69-75. 